Article

\title{
Pyrrolizidine Alkaloids and Fatty Acids from the Endemic Plant Species Rindera umbellata and the Effect of Lindelofine- $N$-oxide on Tubulin Polymerization
}

Boris M. Mandić ${ }^{1, *}$, Milena R. Simić ${ }^{2}$, Ivan M. Vučković ${ }^{1}$, Ljubodrag V. Vujisić ${ }^{1}$,

Miroslav M. Novaković ${ }^{3}$, Snežana S. Trifunović ${ }^{1}$, Snežana D. Nikolić-Mandić ${ }^{1}$, Vele V. Tešević ${ }^{1}$, Vlatka V. Vajs ${ }^{3}$ and Slobodan M. Milosavljević ${ }^{1}$

1 Faculty of Chemistry University of Belgrade, Studentski trg 16, Belgrade 11158, Serbia; E-Mails: ivuckovic@chem.bg.ac.rs (I.M.V.); ljubaw@chem.bg.ac.rs (L.V.V.); snezanat@chem.bg.ac.rs (S.S.T.); snezananm@chem.bg.ac.rs (S.D.N.-M.); vtesevic@chem.bg.ac.rs (V.V.T.); smilo@chem.bg.ac.rs (S.M.M.)

2 Faculty of Pharmacy University of Belgrade, Vojvode Stepe 450, Belgrade 11000, Serbia; E-Mail: milena@pharmacy.bg.ac.rs

3 Institute of Chemistry, Technology and Metallurgy University of Belgrade, Njegoseva 12, Belgrade 11000, Serbia; E-Mails: mironov@chem.bg.ac.rs (M.M.N.); vajs@chem.bg.ac.rs (V.V.V.)

* Author to whom correspondence should be addressed; E-Mail: borism@chem.bg.ac.rs; Tel.: +381-11-2630-474; Fax: +381-11-2636-061.

Received: 20 July 2013; in revised form: 10 August 2013 / Accepted: 27 August 2013 / Published: 3 September 2013

\begin{abstract}
The examination of the aerial parts, roots, and seeds of the endemic plant Rindera umbellata is reported in this paper for the first time. Phytochemical investigation of $R$. umbellata led to the isolation and characterization of ten pyrrolizidine alkaloids and eleven fatty acids in the form of triglycerides. Pyrrolizidine alkaloids 1-9 were found in the aerial parts, 7 and $\mathbf{8}$ in the roots, and 6-10, together with eleven fatty acids, in the seeds of this plant species. The structures of compounds 1-10 were established based on spectroscopic studies $\left({ }^{1} \mathrm{H}\right.$ - and ${ }^{13} \mathrm{C}-\mathrm{NMR}, 2 \mathrm{D}$ NMR, IR and CI-MS). After trans-esterification, methyl esters of the fatty acids were analyzed using GC-MS. The effect of lindelofine- $N$-oxide (7) on tubulin polymerization was determined.
\end{abstract}

Keywords: Rindera umbellata; pyrrolizidine alkaloids; fatty acids; tubulin polymerization 


\section{Introduction}

The toxic pyrrolizidine alkaloids (PAs) are a large group of secondary metabolites, and it has been estimated that PA-producing plants represent 3\% of all flowering species [1-6]. Despite the fact that PAs have been the subject of investigations for many years, interest in them remains. The investigations of the activities of plant PAs have indicated their neurotoxic, mutagenic, carcinogenic, but also antitumor effects [7-9]. PAs are readily absorbed from the digestive tract and cause harmful effects only after undergoing activation to toxic metabolites in the liver. The effects include a variety of changes in biomolecules leading to permanent damage to genes and chromosomes, the ability of cells to divide, the development of cancer and even cell death. Some PAs are strong toxins for humans and domestic animals [10]. The acute toxicity of PAs varies widely. The rat $L D_{50}$ of most alkaloids known to be significant for human health are in the range of 34-300 mg/kg, although some approach $1,000 \mathrm{mg} / \mathrm{kg}$. On the other hand, many species rich with PAs are used in traditional medicine in Asia and Africa, which makes them a very interesting for phytochemical investigation.

The occurrence of PAs in plants is scattered in several unrelated botanic families: Asteraceae, Boraginaceae, Fabaceae, Apiaceae, Convolvulaceae, Celestraceae, Proteaceae, Santalaceae, Sapotaceae, Ranunculaceae, Euphorbiaceae, Orchidaceae, Scrophulariaceae, and Poaceae. The most important herbal species with PAs originate from the families Asteraceae (Tussilago farfara, Petasites sp., Senecio sp., Adenostyles alliariae, Eupatorium sp.), Boraginaceae (Symphytum sp., Borago officnalis, Anchusa officinalis, Cynoglosum officinale, Echium sp., Heliotropium sp., Lithospermum sp.) and Fabaceae (Crotalaria sp.) [6].

The genus Rindera Pall. belongs to Boraginaceae tribe Cynoglosseae DC. and includes about 25 species mostly distributed in central and western Asia [11]. Rindera umbellata is a biennial to perennial plant, found growing at sandy places in the Danube countries. In Serbia R. umbellata is narrowly distributed in Deliblatska peščara and Ramska peščara and it is only species of the genus which occurs in Serbia. The samples examined in this work were collected in Deliblatska peščara. The genus Rindera is known to be a rich source of PAs [12]. In this study, the PAs from the endemic plant $R$. umbellata were isolated and their structures were elucidated.

The effect of lindelofine- $N$-oxide (7) on tubulin polymerization was determined. Tubulin is a globular protein crucial for cellular replication. It is heterodimer consisting of two closely related $55-\mathrm{kDa}$ polypeptides called $\alpha$-tubulin and $\beta$-tubulin, which polymerize to form hollow cylinders called microtubules. Microtubules exhibit differential dynamic behaviors during different phases of the cell cycle. Inhibition of the microtubule assembly dynamics causes cell cycle arrest leading to apoptosis, qualifying them as important drug targets for treating cancer $[13,14]$. Many anticancer natural products act by inhibiting or promoting the assembly of tubulin to microtubules [15]. To the best of our knowledge PAs have not been studied in this context so far.

The family Boraginaceae is one of the best known sources of fatty acids [16,17]. Fatty acids, which are widely occurred natural products [18-20] and have chemotaxonomic significance in Boraginaceae [17], were also identified in the seeds of this plant material. 


\section{Results and Discussion}

The isolation procedure for PAs from crude extracts of $R$. umbellata yielded ten alkaloids 1-10 (Figure 1, Table 1). Alkaloids 1-9 were isolated from the aerial parts of this plant. The extract of the roots gave PAs $\mathbf{7}$ and $\mathbf{8}$. From the seeds of $R$. umellata PAs 6-10 were isolated. Three plant samples collected in different years were examined and yields of PAs depending on the plant's parts and time of harvest are given in Table 2 .

Figure 1. Structures of compounds 1-10.

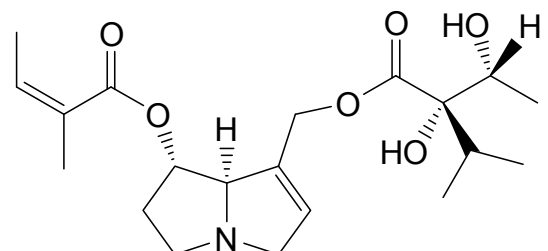

1<smiles>C/C=C(/C)C(=O)O[C@H]1CCN2CC[C@H](COC(=O)[C@](O)(C(C)C)[C@@H](C)O)[C@H]12</smiles>

3<smiles>C/C=C(/C)C(=O)O[C@H]1CCN2CC=C(CO)[C@H]12</smiles>

5

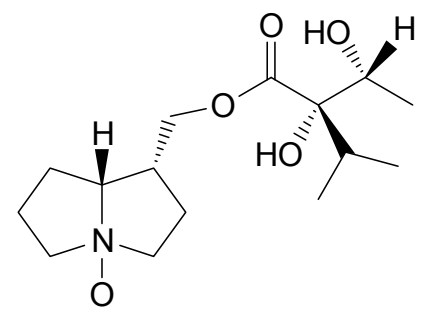

7

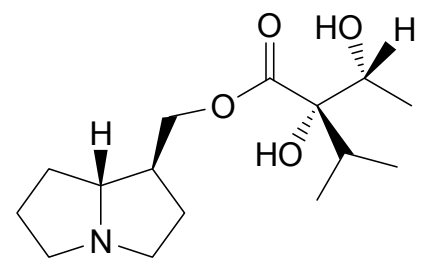

9<smiles>CC[C@](O)(C(C)C)[C@H](O)C(=O)OC[C@H]1CCN2CCC[C@H]12</smiles>

2<smiles>C/C=C(/C)C(=O)O[C@H]1CCN2CC[C@H](CO)[C@H]12</smiles>

4<smiles>C/C=C(/C)C(=O)O[C@H]1CCN2CC=C(COC(=O)[C@@](O)(C(C)C)[C@@H](O)C(C)C)[C@H]12</smiles>

6<smiles>C/C=C(/C)C(=O)O[C@H]1CCN2CC=C(COC(=O)[C@@](O)(C(C)C)[C@@H](C)O)[C@H]12</smiles>

8

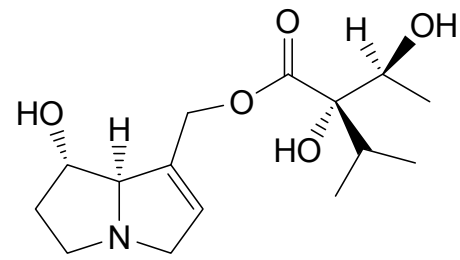

10 
Table 1. IUPAC and common names of isolated PAs.

\begin{tabular}{|c|c|c|}
\hline $\begin{array}{c}\text { Compound } \\
\text { number }\end{array}$ & IUPAC name & Common name \\
\hline 1 & $\begin{array}{l}(Z)-((1 S, 7 \mathrm{a} R)-7-(((2 S, 3 R)-2,3 \text {-dihydroxy-2-isopropylbutanoyloxy) } \\
\text { methyl)-2,3,5,7a-tetrahydro-1H-pyrrolizin-1-yl)2-methylbut-2-enoate }\end{array}$ & $\begin{array}{l}\text { 7-Angeloyl-9-(+)- } \\
\text { trachelanthylheliotridine }\end{array}$ \\
\hline 2 & $\begin{array}{l}(2 S, 3 R)-((1 R, 7 \mathrm{a} R) \text {-hexahydro-1 } H \text {-pyrrolizin-1-yl }) \\
\text { methyl2,3-dihydroxy-2-isopropylbutanoate }\end{array}$ & Lindelofine \\
\hline 3 & $\begin{array}{l}(Z)-((1 R, 7 S, 7 \mathrm{a} S)-7-(((2 S, 3 R)-2,3 \text {-dihydroxy-2-isopropylbutanoyloxy) } \\
\text { methyl)hexahydro-1 } H \text {-pyrrolizin-1-yl) 2-methylbut-2-enoate }\end{array}$ & Punctanecine \\
\hline 4 & $\begin{array}{l}(Z)-((1 S, 7 S, 7 \mathrm{a} R)-7 \text {-(hydroxymethyl) } \\
\text { hexahydro-1H-pyrrolizin-1-yl) 2-methylbut-2-enoate }\end{array}$ & 7-Angeloyl heliotridane \\
\hline 5 & $\begin{array}{l}\text { (Z)-((1S,7a } R) \text {-7-(hydroxymethyl)-2,3,5, } \\
\text { 7a-tetrahydro-1H-pyrrolizin-1-yl) 2-methylbut-2-enoate }\end{array}$ & 7-Angeloyl heliotridine \\
\hline 6 & $\begin{array}{l}(Z)-((1 S, 7 \mathrm{a} R)-7-(((R)-2,3-d i h y d r o x y-2-((R)-1 \text {-hydroxyethyl)-3- } \\
\text { methylbutanoyloxy)methyl)-2,3,5, } \\
\text { 7a-tetrahydro-1H-pyrrolizin-1-yl) 2-methylbut-2-enoate }\end{array}$ & Heliosupine \\
\hline 7 & $\begin{array}{l}(2 S, 3 R)-((1 R, 7 \mathrm{a} R) \text {-hexahydro-1 } H \text {-pyrrolizin-1-yl }) \\
\text { methyl2,3-dihydroxy-2-isopropylbutanoate- } N \text {-oxide }\end{array}$ & Lindelofine- $N$-oxide \\
\hline 8 & $\begin{array}{l}(Z)-((1 S, 7 \mathrm{a} R)-7-(((R)-2,3-\text { dihydroxy-2-((R)-1-hydroxyethyl)-3- } \\
\text { methylbutanoyloxy)methyl)-2,3,5, } \\
\text { 7a-tetrahydro-1H-pyrrolizin-1-yl) 2-methylbut-2-enoate- } N \text {-oxide }\end{array}$ & Heliosupine- $N$-oxide \\
\hline 9 & $\begin{array}{l}(2 S, 3 R)-((1 S, 7 \mathrm{a} R) \text {-hexahydro-1 } H \text {-pyrrolizin-1-yl }) \\
\text { methyl 2,3-dihydroxy-2-isopropylbutanoate }\end{array}$ & $\begin{array}{l}\text { 9-(+)-Trachelanthyl- } \\
\quad \text { laburnine }\end{array}$ \\
\hline 10 & $\begin{array}{l}(2 S, 3 R)-((1 \mathrm{~S}, 7 \mathrm{a} R)-1 \text {-hydroxy-2,3,5,7a-tetrahydro-1 } H \text {-pyrrolizin-7-yl }) \\
\text { methyl 2,3-dihydroxy-2-isopropylbutanoate }\end{array}$ & Echinatine \\
\hline
\end{tabular}

Table 2. Quantities of PAs isolated from different parts of Rindera umbellata, in relation to time of harvest $(\mathrm{mg} / \mathrm{kg})$.

\begin{tabular}{ccccc}
\hline PA & $\begin{array}{c}\text { Jun 2007 } \\
\text { dry aerial parts }\end{array}$ & $\begin{array}{c}\text { May 2008 } \\
\text { dry aerial parts }\end{array}$ & $\begin{array}{c}\text { May 2008 } \\
\text { dry roots }\end{array}$ & $\begin{array}{c}\text { July 2009 } \\
\text { dry seeds }\end{array}$ \\
\hline $\mathbf{1}$ & & 37.2 & & \\
$\mathbf{2}$ & 233.3 & 141.6 & & 66.9 \\
$\mathbf{3}$ & 7.1 & & & \\
$\mathbf{4}$ & & 30.6 & & \\
$\mathbf{5}$ & 5.7 & & & 233.8 \\
$\mathbf{6}$ & 143.8 & 110 & 113.2 & 94.4 \\
$\mathbf{7}$ & 2051.0 & & 130.3 & 62.5 \\
$\mathbf{8}$ & 238.6 & 270.2 & & 63.8 \\
$\mathbf{9}$ & 91.9 & & & \\
$\mathbf{1 0}$ & & & & \\
\hline
\end{tabular}

The structural assignments of alkaloids were based on comparison of their spectral data with those in literature $[21,22]$. 
In general, according to their necine bases, PAs could be classified into four types: heliotridine-type, platynecine-type, otonecine-type and retronecine-type. Retronecine and heliotridine are enantiomers at the C7 position, and besides otonecine-type PAs, have received the most attention because of their abundance and potent toxicities [6].

A rough estimation of PAs distribution within families Asteraceae and Boraginaceae indicated otonecine-type and heliotridine-type compounds as the main PAs, respectively. Retronecine-type PAs could be found in Fabaceae species, and also in Asteraceae and Boraginaceae species [6,12,23].

Most of isolated PAs from $R$. umbellata belong to the heliotridine-type. Correspondingly, heliotridine-type PAs were dominant in previously examined Rindera species: $R$. austroechinata, $R$. baldschuanica, $R$. cyclodonta, $R$. echanata and $R$. oblongifolia [12]. Echinatine was present in all of them, including $R$. umbellata, and it could be considered as a characteristic of the genus, although not enough Rindera species have been examined yet in order to conclude about PAs as chemical markers for distinguishing species within the genus.

Fatty acids of only few species of the genus Rindera have been previously analyzed and a new $\mathrm{C}_{10}$ unsaturated fatty acid (obtusilic acid) was found in the nuts of $R$. obtusiloda [24]. $\gamma$-Linolenic acid was identified in the seed oils of Rindera lanata and $R$. umbellata within a search of 33 species of the family Boraginaceae for a preferred source of this acid [25]. More detailed study of 45 species of the family confirmed that it is one of the best known sources of $\gamma$-linolenic acid, which is actually unusual in plants, but much appreciated because of its nutritional and medical benefits. Whereas in other families of angiosperms this acid is exclusively present in one or few genera, it has been found in most of the species of Boraginaceae evaluated to date, being absent or at very low concentrations only in the tribes Cordioideae, Ehretioideae and Heliotropioideae. Besides the presence of $\gamma$-linolenic acid, the concentration of linoleic, $\alpha$ - and $\gamma$-linolenic acid, stearidonic acid and erucic acid are of special chemotaxonomic importance within this family and follows some general rules at the tribal level. Regarding the tribe Cynoglosseae DC., the maximum concentrations of long-chain mono-unsaturated fatty acids were present in the comparison with other tribes of the family [17].

From the seeds of $R$. umbellata eleven fatty acids were isolated in the form of triglycerides. Fatty acids isolated from seeds were analysed after transesterification as methyl esters using GC-MS/FID. Palmitic (3.25\%), linolenic (1.99\%), linolic $(16.60 \%)$, oleic $(62.65 \%)$, stearic $(1.40 \%)$, eicosenic (3.80\%), eicosanic (trace), erucic (4.25\%), docosanic (trace), nervonic (trace) and tetracosanic (trace) acids were identified by MS and their content was determined by FID. Due to the limited data about fatty acids in the genus Rindera, these data could not be appropriately interpreted within the genus, but it corresponds well to known facts about the fatty acids in the tribe Cynoglosseae DC. Although the high content of oleic acid was noticed in other analyzed plants of the tribe $(24.0 \%-47.3 \%)$, R. umbelata differs due to the extremely high content of this monounsaturated acid $(62.65 \%)$.

The effect of lindelofine- $N$-oxide on tubulin polymerization was tested. Different concentrations of lindelofine- $N$-oxide $(1,10,50$ and $100 \mu \mathrm{M}$ were incubated with tubulin solution and microtubule assembly was examined. The $\mathrm{IC}_{50}$ value for lindelofine- $N$-oxide was $91 \mu \mathrm{M}$, while the $\mathrm{IC}_{50}$ value for paclitaxel was $2.4 \mu \mathrm{M}$. Lindelofine- $N$-oxide thus exhibited a moderate effect on tubulin polymerization in comparison with paclitaxel. To the best of our knowledge effects of PAs on tubulin polymerization have not been previously studied. Despite the modest activity of lindelofine- $N$-oxide in this test, other 
PAs should be tested to verify their influence on tubulin polymerization and acting on this way as anticancer substances.

\section{Experimental Section}

\subsection{General}

The IR spectra were measured in the form of $\mathrm{KBr}$ pellets on a Perkin-Elmer FT-IR spectrometer 1725X. NMR spectra were recorded on a Varian Gemini 2000 (200 MHz for ${ }^{1} \mathrm{H}$ ) and a Bruker Avance III $500\left(500 \mathrm{MHz}\right.$ for $\left.{ }^{1} \mathrm{H}\right)$ spectrometer with $\mathrm{CDCl}_{3}$ and $\mathrm{CD}_{3} \mathrm{OD}$ as solvents and TMS as reference. The mass spectra were obtained on a Finnigan MAT 8230, BE DCI (150 eV, isobutane).

GC-MS analyses were performed on an Agilent 7890A GC system equipped with a 5975C inert XL EI/CI MSD and a FID detector connected by capillary flow technology through a 2-way splitter with make-up gas. An HP-5 MS capillary column (Agilent Technologies, Santa Clara, CA, USA, 25 mm i.d., $30 \mathrm{~m}$ length, $0.25 \mu \mathrm{m}$ film thickness) was used.

Silica gel, $0.008 \mathrm{~mm}$ (Merck, Darmstadt, Germany), was used for preparative column chromatography (CC) and silica gel F-254 (Merck, Darmstadt, Germany) for analytical and preparative thin layer chromatography (TLC). The solvents were purified by distillation before use.

\subsection{Plant Material}

The plant material was collected during its flowering and fructification period in Deliblatska peščara, Serbia (June 2007, May 2008 and July 2009.). All tree harvests were performed at Latitude $\mathrm{N} 44^{\circ} 57^{\prime} 58^{\prime \prime}$ and Longitude E $21^{\circ} 1^{\prime} 48^{\prime \prime}$. Voucher specimens are deposited in the Herbarium of the Faculty of Biology, University of Belgrade.

\subsection{Extraction and Isolation of PAs}

The R. umbellata plant materials were air-dried at room temperature for 15 days.

\subsubsection{Harvest I (June 2007)}

The dried and powdered aerial parts $(210 \mathrm{~g})$ were extracted with methanol $(1.0 \mathrm{~L})$ for 5 days at room temperature using an ultrasonic bath. After filtration and solvent removal, the residue $(22 \mathrm{~g})$ was dissolved in $1 \mathrm{M}$ sulfuric acid and the $\mathrm{pH}$ adjusted to $\mathrm{pH}$ 2. The mixture was extracted with $\mathrm{CH}_{2} \mathrm{Cl}_{2}$ $(2 \times 70 \mathrm{~mL})$. The aqueous layer was then made alkaline $\left(\mathrm{pH}\right.$ 9.0) with $\mathrm{NH}_{4} \mathrm{OH}$, and extracted with $\mathrm{CH}_{2} \mathrm{Cl}_{2}(3 \times 150 \mathrm{~mL})$. As the aqueous layer showed a positive Dragendorff test, it was extracted with $n$-butanol $(2 \times 50 \mathrm{~mL})$. Both organic layers were dried with anhydrous magnesium sulphate. After filtration and solvent removal under reduced pressure, residues were purified by silica gel CC and prep. TLC to yield pure alkaloids. The first extract (16 g, from $\mathrm{CH}_{2} \mathrm{Cl}_{2}$,) was purified by column chromatography [silica gel, $\mathrm{CH}_{2} \mathrm{Cl}_{2}$-methanol- $\mathrm{NH}_{4} \mathrm{OH}$ (9:1:0.1)] and the polarity was gradually increased. One fraction was a mixture of two components $(5 \mathrm{mg})$. After purification of the mixture by prep. TLC $\left(\mathrm{CH}_{2} \mathrm{Cl}_{2}\right.$-methanol 9:1) $3(1.5 \mathrm{mg})$ and $\mathbf{5}(1.2 \mathrm{mg})$ were isolated as a pure compounds. The results are shown in Table 2 . The second extract ( $2 \mathrm{~g}$, from $n-\mathrm{BuOH})$ was purified by column 
chromatography $\left(n-\mathrm{BuOH} / \mathrm{MeOH} / \mathrm{H}_{2} \mathrm{O} / \mathrm{NH}_{3}\right.$ 70:15:10:5 v/v). The yield of isolated compound 7 was $430.7 \mathrm{mg}$ (Table 2). The spots were detected under $\mathrm{UV}_{254}$, by Dragendorff reagent or by spraying with $50 \% \mathrm{H}_{2} \mathrm{SO}_{4}$.

\subsubsection{Harvest II (May 2008)}

The dried and powdered aerial parts $(500 \mathrm{~g})$ were extracted with methanol $(2.4 \mathrm{~L})$ for 5 days at room temperature using an ultrasonic bath. After filtration and solvent removal, the residue (38 $\mathrm{g}$ ) was dissolved in $1 \mathrm{M}$ sulfuric acid and the $\mathrm{pH}$ adjusted to $\mathrm{pH} \sim 2$. The mixture was extracted with $\mathrm{CH}_{2} \mathrm{Cl}_{2}$ $(2 \times 100 \mathrm{~mL})$. The aqueous layer was then made alkaline $(\mathrm{pH} 9.0)$ with $\mathrm{NH}_{4} \mathrm{OH}$, and extracted with $\mathrm{CH}_{2} \mathrm{Cl}_{2}(3 \times 200 \mathrm{~mL})$. The aqueous layer showed a negative Dragendorff test. The organic layer was dried with anhydrous magnesium sulphate. After filtration and solvent removal under reduced pressure the residue $(17 \mathrm{~g})$ was purified by column chromatography [silica gel, $\mathrm{CH}_{2} \mathrm{Cl}_{2}$-methanol- $\mathrm{NH}_{4} \mathrm{OH}$ (9:1:0.1)]. The yields of isolated compounds are shown in Table 2.

The dried and powdered roots $(310 \mathrm{~g})$ were extracted with methanol $(1.0 \mathrm{~L})$ for 5 days at room temperature using an ultrasonic bath. After filtration and solvent removal, the residue (10 g) was dissolved in $1 \mathrm{M}$ sulfuric acid and the $\mathrm{pH}$ adjusted to $\mathrm{pH} 2$. The mixture was extracted with $\mathrm{CH}_{2} \mathrm{Cl}_{2}$ $(2 \times 50 \mathrm{~mL})$. The aqueous layer was then made alkaline $\left(\mathrm{pH}\right.$-9.0) with $\mathrm{NH}_{4} \mathrm{OH}$, extracted with $\mathrm{CH}_{2} \mathrm{Cl}_{2}$ $(3 \times 50 \mathrm{~mL})$. As the aqueous layer showed a positive Dragendorff test, it was extracted with $n$-butanol $(2 \times 50 \mathrm{~mL})$. Both organic layers were dried with anhydrous magnesium sulphate. After filtration and solvent removal under reduced pressure residues were purified by silica gel CC to yield pure alkaloids. The first extract ( $3 \mathrm{~g}$, from $\mathrm{CH}_{2} \mathrm{Cl}_{2}$ ) was purified by column chromatography [silica gel, $\mathrm{CH}_{2} \mathrm{Cl}_{2}$-methanol- $\left.\mathrm{NH}_{4} \mathrm{OH} \quad(9: 1: 0.1)\right]$. Only compound $8(40.4 \mathrm{mg})$ was isolated from the dichloromethane extract. The second extract $(3.7 \mathrm{~g}$, from $n$-BuOH) was purified by column chromatography ( $n-\mathrm{BuOH}-\mathrm{MeOH}-\mathrm{H}_{2} \mathrm{O}-\mathrm{NH}_{3}$ 70:15:10:5, v/v). Only compound 7 (35.1 mg) was isolated from the butanolic extract (Table 2).

\subsubsection{Harvest III (July 2009)}

The dried and powdered seeds (160 g) were extracted with methanol $(0.6 \mathrm{~L})$ for 5 days at room temperature using an ultrasonic bath. After filtration and solvent removal, the residue (22 g) was dissolved in $1 \mathrm{M}$ sulfuric acid and the $\mathrm{pH}$ adjusted to $\mathrm{pH} \sim 2$. The mixture was extracted with $\mathrm{CH}_{2} \mathrm{Cl}_{2}$ $(2 \times 50 \mathrm{~mL})$. The aqueous layer was then made alkaline $\left(\mathrm{pH}\right.$-9.0) with $\mathrm{NH}_{4} \mathrm{OH}$, extracted with $\mathrm{CH}_{2} \mathrm{Cl}_{2}$ $(3 \times 50 \mathrm{~mL})$. As the aqueous layer showed a positive Dragendorff test, it was extracted with $n$-butanol $(2 \times 30 \mathrm{~mL})$. Both organic layers were dried with anhydrous magnesium sulphate. After filtration and solvent removal under reduced pressure residues were purified by silica gel CC to yield pure alkaloids. The first extract $\left(343 \mathrm{mg}\right.$, from $\mathrm{CH}_{2} \mathrm{Cl}_{2}$ ) was purified by column chromatography [silica gel, $\mathrm{CH}_{2} \mathrm{Cl}_{2}$-methanol- $\mathrm{NH}_{4} \mathrm{OH}$ (9:1:0.1)]. The quantities of isolated compounds are shown in Table 2. The butanolic extract $(1.0 \mathrm{~g})$ was purified by column chromatography ( $n$-BuOH-MeOH-H $\mathrm{H}_{2} \mathrm{O}-\mathrm{NH}_{3}$ $70: 15: 10: 5, \mathrm{v} / \mathrm{v})$. Only compound $7(15.1 \mathrm{mg})$ was isolated (Table 2$)$ from the butanolic extract. 


\subsection{Compound Characterization}

\subsubsection{Compound 1}

Colorless oil; CIMS $[\mathrm{M}+\mathrm{H}]^{+} \mathrm{m} / z$ 382; ${ }^{1} \mathrm{H}-\mathrm{NMR}\left(200 \mathrm{MHz}, \mathrm{CDCl}_{3}\right) \delta$ : $6.2\left(1 \mathrm{H}, \mathrm{qq}, J_{1}=6.9 \mathrm{~Hz}\right.$, $\left.J_{2}=1.4 \mathrm{~Hz}, \mathrm{H}-3 "\right), 5.85(1 \mathrm{H}$, br s, H-2), 5.17 (1H, br s, H-7), 4.95 (2H, br s, H-9), 4.09 (1H, q, $J=6.4 \mathrm{~Hz}, \mathrm{H}-3$ '), 4.06 (1H, m, H-8), 3.96 (1H, br d, H-3b), 3.36 (1H, m, H-3a), 3.20 (1H, m, H-5b), $2.86(1 \mathrm{H}, \mathrm{m}, \mathrm{H}-5 \mathrm{a}), 2.08$ (1H, m, $\left.J=6.9 \mathrm{~Hz}, \mathrm{H}-5^{\prime}\right), 1.98$ (3H, m, $\left.J_{I}=6.9 \mathrm{~Hz}, J_{2}=1.4 \mathrm{~Hz}, \mathrm{H}-4 "\right), 1.92$ (2H, m, H-6), 1.87 (3H, m, J=1.4 Hz, H-5"), 1.27 (3H, d, $J=6.4 \mathrm{~Hz}, \mathrm{H}-4$ '), 0.94 (3H, d, $J=6.6 \mathrm{~Hz}$, H-6'), 0.93 (3H, d, $\left.J=6.9 \mathrm{~Hz}, \mathrm{H}-7^{\prime}\right) ;{ }^{13} \mathrm{C}-\mathrm{NMR}\left(50 \mathrm{MHz}, \mathrm{CDCl}_{3}\right) \delta: 175.2$ (s, C-1'), 168.1 (s, C-1"), 138.9 (d, C-3"), 134.5 (s, C-1), 129.3 (d, C-2), 127.6 (s, 2"), 82.9 (s, 2'), 79.2 (d, C-8), 76.9 (d, C-7), 69.3 (d, C-3'), 62.2 (t, C-3), 62.2 (t, C-9), 54.2 (t, C-5), 32.8 (d, C-5'), 30.2 (t, C-6), 20.4 (q, C-5"), 17.3 (q, C-4'), 17.1 (q, C-6'), 16.7 (q, C-7'), 15.8 (q, C-4').

\subsubsection{Compound 2}

White crystals; CIMS $[\mathrm{M}+\mathrm{H}]^{+} \mathrm{m} / z$ 286; ${ }^{1} \mathrm{H}-\mathrm{NMR}\left(200 \mathrm{MHz}, \mathrm{CDCl}_{3}\right) \delta: 4.30(2 \mathrm{H}, \mathrm{br} \mathrm{d}, J=7.2 \mathrm{~Hz}$, H-9), 4.09 (1H, q, J = 6.4 Hz, H-3'), 3.66 (1H, m, H-8), 3.43 (1H, m, H-3a), 2.91 (1H, m, H-5a), 2.65 (1H, m, H-5b), 2.50 (1H, m, H-3b), 2.00 (1H, m, H-1), 1.96 (1H, m, H-5'), 1.70 (2H, m, H-2), 1.60 (2H, m, H-6), 1.53 (2H, m, H-7), 1.21 (3H, d, $\left.J=6.2 \mathrm{~Hz}, \mathrm{H}-4^{\prime}\right), 0.97$ (3H, d, $\left.J=7.2 \mathrm{~Hz}, \mathrm{H}-7^{\prime}\right), 0.92$ $\left(3 \mathrm{H}, \mathrm{d}, J=6.6 \mathrm{~Hz}, \mathrm{H}-6{ }^{\prime}\right) ;{ }^{13} \mathrm{C}-\mathrm{NMR}\left(50 \mathrm{MHz}, \mathrm{CDCl}_{3}\right) \delta: 174.8$ (s, C-1'), 83.0 (s, C-2'), 69.1 (d, C-3'), 67.0 (d, C-8), 64.4 (t, C-9), 55.7 (t, C-5), 53.6 (t, C-3), 39.8 (d, C-1), 32.9 (d, C-5'), 26.2 (t, C-2), 25.8 (t, C-7), 25.7 (t, C-6), 16.9 (q, C-7'), 16.8 (q, C-6'), 16.4 (q, C-4').

\subsubsection{Compound 3}

Colorless oil; CIMS $[\mathrm{M}+\mathrm{H}]^{+} \mathrm{m} / z$ 384; ${ }^{1} \mathrm{H}-\mathrm{NMR}\left(200 \mathrm{MHz}, \mathrm{CDCl}_{3}\right) \delta: 6.10\left(1 \mathrm{H}, \mathrm{qq}, J_{1}=7.9 \mathrm{~Hz}\right.$, $\left.J_{2}=1.4 \mathrm{~Hz}, \mathrm{H}-3 "\right), 5.10$ (1H, dd , H-7), 4.38 (2H, dd, H-9), 4.04 (1H, m, H-3'), 3.60 (1H, m, H-8), 3.22 $(1 \mathrm{H}, \mathrm{m}, \mathrm{H}-3 \mathrm{~b}), 2.66(1 \mathrm{H}, \mathrm{m}, \mathrm{H}-3 \mathrm{a}), 3.02(1 \mathrm{H}, \mathrm{m}, \mathrm{H}-5 \mathrm{~b}), 2.75(1 \mathrm{H}, \mathrm{m}, \mathrm{H}-5 \mathrm{a}), 2.14(1 \mathrm{H}, \mathrm{m}$, $\left.J=6.6 \mathrm{~Hz}, \mathrm{H}-5^{\prime}\right), 2.02$ (2H, m, H-2), 2.00 (1H, m, H-1), 2.00 (1H, m, H-6b), 1.97 (3H, m, $J_{1}=7.4 \mathrm{~Hz}$, $\left.J_{2}=1.4 \mathrm{~Hz}, \mathrm{H}-4 "\right), 1.94$ (1H, m, H-6a), 1.87 (3H, m, $\left.J=1.4 \mathrm{~Hz}, \mathrm{H}-5 "\right), 1.21$ (3H, d, $J=6.6 \mathrm{~Hz}, \mathrm{H}-4$ '), $0.93\left(3 \mathrm{H}, \mathrm{d}, J=6.8 \mathrm{~Hz}, \mathrm{H}-6{ }^{\prime}\right), 0.92\left(3 \mathrm{H}, \mathrm{d}, J=6.9 \mathrm{~Hz}, \mathrm{H}-7^{\prime}\right)$.

\subsubsection{Compound 4}

Colorless oil; CIMS [M+H] ${ }^{+} m / z$ 240; ${ }^{1} \mathrm{H}-\mathrm{NMR}\left(200 \mathrm{MHz}, \mathrm{CDCl}_{3}\right) \delta: 6.13\left(1 \mathrm{H}, \mathrm{qq}, J_{1}=7.3 \mathrm{~Hz}\right.$, $\left.J_{2}=1.4 \mathrm{~Hz}, \mathrm{H}-3 "\right), 5.19$ (1H, m, H-7), 3.79 (2H, d, $\left.J=6.9 \mathrm{~Hz}, \mathrm{H}-9\right), 3.50$ (1H, m, H-8), 3.24 (1H, m, H-5b), 3.06 (1H, m, H-3b), 2.83 (1H, m, H-5a), 2.63 (1H, m, H-3a), 2.63 (1H, m, H-1), 2.00 (2H, m, H-6), 1.99 (3H, m, $\left.J_{l}=7.2 \mathrm{~Hz}, J_{2}=1.4 \mathrm{~Hz}, \mathrm{H}-4 "\right), 1.86$ (3H, m, H-5"), 1.40 (2H, m, H-2); ${ }^{13} \mathrm{C}-\mathrm{NMR}$

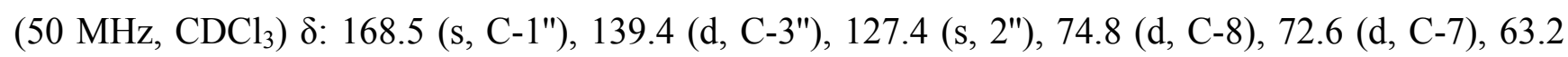
(t, C-9), 54.3 (t, C-3), 53.8 (t, C-5), 44.5 (d, C-1), 32.7 (t, C-6), 28.8 (t, C-2), 20.4 (q, C-5"), 15.9 (q, C-4"). 


\subsubsection{Compound 5}

Colorless oil; CIMS [M+H] ${ }^{+} m / z 238 ;{ }^{1} \mathrm{H}-\mathrm{NMR}\left(200 \mathrm{MHz}, \mathrm{CDCl}_{3}\right) \delta: 6.13\left(1 \mathrm{H}, \mathrm{qq}, J_{1}=6.5 \mathrm{~Hz}\right.$, $\left.J_{2}=1.4 \mathrm{~Hz}, \mathrm{H}-3 "\right), 5.62(1 \mathrm{H}$, br s, H-2), 5.12 (1H, m, C-7), 4.36 (2H, br s, H-9), 4.06, (1H, m, H-8), 3.90 (1H, m, H-3b), 3.32 (1H, m, H-3a), 3.16 (1H, m, H-5b), 2.85 (1H, m, H-5a), 2.00 (3H, m, J = 7.4 Hz, $\left.J_{2}=1.4 \mathrm{~Hz}, \mathrm{H}-4 "\right), 1.91$ (2H, m, H-6), 1.87 (3H, m, $\left.J=1.4 \mathrm{~Hz}, \mathrm{H}-5 "\right)$.

\subsubsection{Compound 6}

Yellow oil; EIMS $[\mathrm{M}]^{+} \mathrm{m} / z$ 397; ${ }^{1} \mathrm{H}-\mathrm{NMR}\left(500 \mathrm{MHz}, \mathrm{CDCl}_{3}\right) \delta: 6.16\left(1 \mathrm{H}, \mathrm{qq}, J_{1}=7.2 \mathrm{~Hz}\right.$, $\left.J_{2}=1.5 \mathrm{~Hz}, \mathrm{H}-3 "\right), 5.92(1 \mathrm{H}$, br s, H-2), $5.24(1 \mathrm{H}, \mathrm{m}, \mathrm{H}-7), 5.04(1 \mathrm{H}$, br d, $J=13 \mathrm{~Hz}, \mathrm{H}-9 \mathrm{a}), 4.93(1 \mathrm{H}$, br d, $J=13 \mathrm{~Hz}, \mathrm{H}-9 \mathrm{~b}), 4.21(1 \mathrm{H}, \mathrm{q}, J=6.5 \mathrm{~Hz}, \mathrm{H}-3$ '), 4.41 (1H, m, H-8), 4.16 (1H, m, H-3a), 3.47 (1H, m, H-3b), 3.38 (1H, m, H-5a), 2.97 (1H, m, H-5b), 2.04 (2H, m, H-6), 1.98 (3H, dq, $J_{1}=7.2 \mathrm{~Hz}$, $\left.J_{2}=1.5 \mathrm{~Hz}, \mathrm{H}-4^{\prime \prime}\right), 1.88$ (3H, m, $\left.J=1.5 \mathrm{~Hz}, \mathrm{H}-5 "\right), 1.30$ (3H, s, H-7'), 1.28 (3H, d, J=7.0 Hz, H-4'), $1.26\left(3 \mathrm{H}, \mathrm{s}, \mathrm{H}-6\right.$ '); ${ }^{13} \mathrm{C}-\mathrm{NMR}\left(125 \mathrm{MHz}, \mathrm{CDCl}_{3}\right) \delta: 174.3$ (s, C-1'), 168.1 (s, C-1"), 139.8 (s, C-1), 139.7 (d, C-3"), 128.9 (d, C-2), 127.2 (s, 2"), 82.8 (s, 2'), 79.1 (d, C-8), 76.7 (d, C-7), 73.8 (s, C-5'), 69.8 (d, C-3'), 62.0 (t, C-9), 61.9 (t, C-3), 54.1 (t, C-5), 30.0 (t, C-6), 25.9 (q, C-6'), 24.8 (q, C-7'), 20.4 (q, C-5"), 18.5 (q, C-4'), 15.9 (q, C-4").

\subsubsection{Compound 7}

White crystals; CIMS $[\mathrm{M}+\mathrm{H}]^{+} \mathrm{m} / z$ 302; ${ }^{1} \mathrm{H}-\mathrm{NMR}\left(600 \mathrm{MHz}, \mathrm{CDCl}_{3}\right) \delta: 4.28\left(1 \mathrm{H}, \mathrm{dd}, J_{1}=10.8 \mathrm{~Hz}\right.$, $\left.J_{2}=8.4 \mathrm{~Hz}, 9 \mathrm{a}\right), 4.14\left(1 \mathrm{H}, \mathrm{m}, J_{1}=11.4 \mathrm{~Hz}, J_{2}=6.6 \mathrm{~Hz}, 9 \mathrm{~b}\right), 4.10(1 \mathrm{H}, \mathrm{m}, \mathrm{H}-8), 4.08(1 \mathrm{H}, \mathrm{q}$, $J=6.6 \mathrm{~Hz}, \mathrm{H}-3$ '), 3.73 (1H, m, H-5b), 3.66 (1H, m, H-3a), 3.62 (1H, m, H-3b), 3.51 (1H, m, H-5b), $3.27(1 \mathrm{H}, \mathrm{m}, J=8,4 \mathrm{~Hz}, \mathrm{H}-1), 2.42(1 \mathrm{H}, \mathrm{m}, \mathrm{H}-2 \mathrm{a}), 2.35(1 \mathrm{H}, \mathrm{m}, \mathrm{H}-6 \mathrm{a}), 2.28(1 \mathrm{H}, \mathrm{m}, \mathrm{H}-7 \mathrm{a}), 1.98(1 \mathrm{H}$, m, H-6b), $1.86(1 \mathrm{H}, \mathrm{m}, J=6.6 \mathrm{~Hz}, \mathrm{H}-5$ ') 1.75 (1H, m, H-2b), 1.69 (1H, m, H-7b), 1.18 (3H, d, $\left.J=6.6 \mathrm{~Hz}, \mathrm{H}-4^{\prime}\right), 0.95$ (3H, d, $\left.J=7,2 \mathrm{~Hz}, \mathrm{H}-7{ }^{\prime}\right), 0.90\left(3 \mathrm{H}, \mathrm{d}, J=7,2 \mathrm{~Hz}, \mathrm{H}-6{ }^{\prime}\right) ;{ }^{13} \mathrm{C}-\mathrm{NMR}(150 \mathrm{MHz}$, $\left.\mathrm{CDCl}_{3}\right) \delta: 175.1\left(\mathrm{~s}, \mathrm{C}-1^{\prime}\right), 83.9$ (d, C-8), 83.5 (s, C-2'), 69.8 (d, C-3'), 69.4 (t, C-5), 68.2 (t, C-3), 63.5 (t, C-9), 37.8 (d, C-1), 33.5 (d, C-5'), 26.6 (t, C-2), 25.1 (t, C-7), 22.8 (t, C-6), 17.6 (q, C-7'), 17.2 (q, C-6'), 16.9 (q, C-4').

\subsubsection{Compound $\mathbf{8}$}

Yellow oil; EIMS [M+16] m/z 397; ${ }^{1} \mathrm{H}-\mathrm{NMR}\left(500 \mathrm{MHz}, \mathrm{CDCl}_{3}\right) \delta$ : $6.22\left(1 \mathrm{H}, \mathrm{qq}, J_{1}=7.2 \mathrm{~Hz}\right.$, $\left.J_{2}=1.5 \mathrm{~Hz}, \mathrm{H}-3 "\right), 6.03$ (1H, br s, H-2), 5.21 (1H, br d, $\left.J=13 \mathrm{~Hz}, \mathrm{H}-9 \mathrm{a}\right), 5.09$ (1H, br s, H-7), 4.86 $(1 \mathrm{H}$, br d, $J=13 \mathrm{~Hz}, \mathrm{H}-9 \mathrm{~b}), 4.73(1 \mathrm{H}, \mathrm{s}, \mathrm{H}-8), 4.58(1 \mathrm{H}, \mathrm{dd}, J=16 \mathrm{~Hz}, \mathrm{H}-3 \mathrm{~b}), 4.46(1 \mathrm{H}, \mathrm{dd}$, $J=16 \mathrm{~Hz}, \mathrm{H}-3 \mathrm{a}), 4.19$ (1H, q, $J=6.5 \mathrm{~Hz}, \mathrm{H}-3$ '), $3.94(1 \mathrm{H}, \mathrm{m}, \mathrm{H}-5 \mathrm{a}), 3.84(1 \mathrm{H}, \mathrm{m}, \mathrm{H}-5 \mathrm{~b}), 2.52(1 \mathrm{H}, \mathrm{m}$, H-6a), 2.26 (1H, m, H-6b), 2.03 (3H, dq, $\left.J_{1}=7.2 \mathrm{~Hz}, J_{2}=1.5 \mathrm{~Hz}, \mathrm{H}-4 "\right), 1.92(3 \mathrm{H}, \mathrm{m}, J=1.5 \mathrm{~Hz}$, H-5"), 1.31 (3H, s, H-7'), 1.27 (3H, d, $\left.J=6.5 \mathrm{~Hz}, \mathrm{H}-4^{\prime}\right), 1.24$ (3H, s, H-6'); ${ }^{13} \mathrm{C}-\mathrm{NMR}-(125 \mathrm{MHz}$, $\left.\mathrm{CDCl}_{3}\right) \delta: 174.3$ (s, C-1'), 167.4 (s, C-1"), 141.2 (d, C-3"), 132.7 (s, C-1), 126.5 (s, 2"), 123.8 (d, C-2), 94.7 (d, C-8), 84.2 (s, C-2'), 77.0 (t, C-3), 73.2 (s, C-5'), 73.1 (d, C-7), 69.6 (d, C-3'), 67.6 (t, C-5), 60.6 (t, C-9), 30.5 (t, C-6), 26.4 (q, C-6'), 24.7(q, C-7'), 20.3 (q, C-5"), 18.6 (q, C-4'), 16.0 (q, C-4"). 


\subsubsection{Compound 9}

Yellow oil; CIMS [M+H] ${ }^{+} \mathrm{m} / z$ 286; ${ }^{1} \mathrm{H}-\mathrm{NMR}\left(200 \mathrm{MHz}, \mathrm{CDCl}_{3}\right) \delta: 4.27(2 \mathrm{H}, \mathrm{m}, J=7.2 \mathrm{~Hz}, \mathrm{H}-9)$, $4.06(1 \mathrm{H}, \mathrm{q}, J=6.4 \mathrm{~Hz}, \mathrm{H}-3$ '), 3.66 (1H, m, H-8), 3.31 (1H, m, H-3a), 3.14 (1H, m, H-5a), 2.65 (1H, m, H-5b), 2.50 (1H, m, H-3b), 2.00 (1H, m, H-1), 1.99 (1H, m, J= 7,0 Hz, H-5'), 1.90 (2H, m, H-2), 1.80 (2H, m, H-6), 1.68 (2H, m, H-7), 1.21 (3H, d, J=6.2 Hz, H-4'), 0.96 (3H, d, J = 7.2 Hz, H-7'), $0.92\left(3 \mathrm{H}, \mathrm{d}, J=6.8 \mathrm{~Hz}, \mathrm{H}-6^{\prime}\right) ;{ }^{13} \mathrm{C}-\mathrm{NMR}\left(50 \mathrm{MHz} \mathrm{CDCl}_{3}\right) \delta: 174.8\left(\mathrm{~s}, \mathrm{C}-1^{\prime}\right), 82.8\left(\mathrm{~s}, \mathrm{C}-2^{\prime}\right), 68.8(\mathrm{~d}$, C-3'), 66.0 (d, C-8), 65.1 (t, C-9), 55.4 (t, C-5), 53.4 (t, C-3), 39.8 (d, C-1), 32.7 (d, C-5'), 26.6 (t, C-2), 25.9 (t, C-7), 25.7 (C-6), 16.8 (q, C-7'), 16.7 (q, C-6'), 16.6 (q, C-4').

\subsubsection{Compound 10}

Colorless oil; EIMS [M] ${ }^{+} \mathrm{m} / z$ 299; ${ }^{1} \mathrm{H}-\mathrm{NMR}$ : (200 MHz, $\left.\mathrm{CDCl}_{3}\right)$ $\delta: 5.72(1 \mathrm{H}$, br s, H-2), 4.90 (2H, $\mathrm{m}, J=13.8 \mathrm{~Hz}, \mathrm{H}-9), 4.25(1 \mathrm{H}, \mathrm{m}, \mathrm{C}-7), 4.19(1 \mathrm{H}, \mathrm{m}, \mathrm{H}-8), 4.03(1 \mathrm{H}, \mathrm{q}, \mathrm{H}-3 \mathrm{a}), 3.97(1 \mathrm{H}, \mathrm{q}$, $\left.J=6.6 \mathrm{~Hz}, \mathrm{H}-3^{\prime}\right), 3.44(1 \mathrm{H}, \mathrm{m}, \mathrm{H}-3 \mathrm{~b}), 3.38(1 \mathrm{H}, \mathrm{m}, \mathrm{H}-5 \mathrm{a}), 2.72(1 \mathrm{H}, \mathrm{m}, \mathrm{H}-5 \mathrm{~b}), 2.18(1 \mathrm{H}, \mathrm{m}$, $\left.J=6.9 \mathrm{~Hz}, \mathrm{H}-5^{\prime}\right), 1.93$ (2H, m, H-6), 1.30 (3H,d, $\left.J=6.6 \mathrm{~Hz}, \mathrm{H}-4^{\prime}\right), 0.93$ (3H, d, $\left.J=6.9 \mathrm{~Hz}, \mathrm{H}-6^{\prime}\right), 0.87$ $\left(3 \mathrm{H}, \mathrm{d}, J=6.9 \mathrm{~Hz}, \mathrm{H}-7^{\prime}\right) ;{ }^{13} \mathrm{C}-\mathrm{NMR}\left(50 \mathrm{MHz}, \mathrm{CDCl}_{3}\right) \delta: 174.1\left(\mathrm{~s}, \mathrm{C}-1^{\prime}\right), 135.7$ (s, C-1), 125.4 (d, C-2), 84.1 (s, C-2'), 79.8 (d, C-8), 73.6 (d, C-7), 71.6 (d, C-3'), 61.7 (t, C-3), 61.4 (t, C-9), 54.3 (t, C-5), 33.4 (t, C-6), 32.2 (d, C-5'), 17.8 (q, C-7'), 17.1 (t, C-4'), 15.7 (q, C-6').

\subsection{Extraction of Fatty Acids and GC-MS/FID Analyses}

The dried and powdered seeds $(10 \mathrm{~g})$ were extracted with petroleum ether $(0.4 \mathrm{~L})$ for 2 days at room temperature using an ultrasonic bath. The solvent was removed under reduced pressure and the residue $(450 \mathrm{mg})$ was dissolved in absolute methanol $(20 \mathrm{~mL})$ containing conc. $\mathrm{H}_{2} \mathrm{SO}_{4}(0.1 \mathrm{~mL})$ and refluxed for two hours. After cooling the reaction mixture, the methanol was removed under reduced pressure and residue was dissolved in water, extracted with $\mathrm{CH}_{2} \mathrm{Cl}_{2}(2 \times 30 \mathrm{~mL})$, neutralised with saturated sodium bicarbonate solution $(2 \times 20 \mathrm{~mL})$ and dried over anhydrous magnesium sulphate. After filtration, the solvent was removed and residue $(254 \mathrm{mg})$ was analysed using GC-MS. Samples were injected in splitless mode. The injection volume was $1 \mu \mathrm{L}$, and the injector temperature was $250{ }^{\circ} \mathrm{C}$. The carrier gas $(\mathrm{He})$ flow rate was $1.1 \mathrm{~mL} / \mathrm{min}$, whereas the column temperature was programmed linearly in a range of $40-240{ }^{\circ} \mathrm{C}$ at a rate of $4{ }^{\circ} \mathrm{C} / \mathrm{min}$. The transfer line temperature was $280{ }^{\circ} \mathrm{C}$. The FID detector temperature was $300^{\circ} \mathrm{C}$. EI mass spectra $(70 \mathrm{eV})$ were acquired in the $\mathrm{m} / \mathrm{z}$ range of 45-450, and the ion source temperature was $230^{\circ} \mathrm{C}$.

\subsection{Tubulin Polymerization}

The effect of lindelofine- $N$-oxide on tubulin polymerization was determined using a standard method [26], with some modifications [27]. Tubulin was isolated from a bovine brain as described previously [28]. Freshly prepared tubulin solution $\left(2.2 \mathrm{mg} \mathrm{mL}^{-1}\right)$ and $\mathrm{MES}$ (2-(N-morpholino) ethanesulfonic acid) buffer containing guanosine triphosphate (GTP) were kept on ice before the experiment. Stock solutions of paclitaxel and lindelofine- $N$-oxide were prepared in DMSO at concentration of $10 \mathrm{mM}$, and afterwards diluted with $\mathrm{DMSO} / \mathrm{H}_{2} 0(1: 1 \mathrm{v} / \mathrm{v})$ to a concentration of $1 \mathrm{mM}$. From this solution, the desired concentrations (in the range of $1-1,000 \mu \mathrm{M}$ ) were prepared in $\mathrm{H}_{2} \mathrm{O}$. 
Solutions $(40 \mu \mathrm{L})$ of various concentrations of either PTX (positive control) or lindelofine- $N$-oxide were added to a tubulin solution $(460 \mu \mathrm{L})$ and incubated for $45 \mathrm{~min}$ at $37^{\circ} \mathrm{C}$. The mixture of MES buffer $(40 \mu \mathrm{L})$ and tubulin $(460 \mu \mathrm{L})$ was used as blank. After incubation, solutions were transferred to UV cuvettes and absorbance was measured at $350 \mathrm{~nm}$ continuously for $15 \mathrm{~min}$ on a GBC Cintra 40 UV-Visible spectrometer equipped with a Petrotest 25-0395 thermostatic circulator cooled to $4{ }^{\circ} \mathrm{C}$. A percentage of tubulin polymerization was determined as difference in absorbance at $t=0 \mathrm{~min}\left(37^{\circ} \mathrm{C}\right)$ and $t=15 \mathrm{~min}\left(4^{\circ} \mathrm{C}\right)$, compared to corresponding difference for the blank. The effect of paclitaxel and lindelofine- $N$-oxide on polymerization of purified tubulin was expressed as concentration of each agent producing $50 \%$ tubulin polymerization $\left(\mathrm{IC}_{50}\right)$.

\section{Conclusions}

To the best of our knowledge this is the first report about phytochemical investigation of Rindera umbellata. Ten PAs were isolated and identified from the aerial parts, roots and seeds of this endemic plant. Eleven fatty acids were also identified from the seeds. The results could be of chemotaxonomic importance, because $R$. umbelatte was examined for the first time. Lindelofine- $N$-oxide exhibited a moderate effect on tubulin polymerization.

\section{Acknowledgments}

The authors acknowledge their gratitude to the Ministry of Education and Science Republic of Serbia for financial support (Project No 172053).

\section{Conflicts of Interest}

The authors declare no conflict of interest.

\section{References}

1. Langel, D.; Ober, D.; Pelser, P. The evolution of pyrrolizidine alkaloid biosynthesis and diversity in the Senecioneae. Phytochem. Rev. 2011, 10, 3-74.

2. Mandic, B.; Godevac, D.; Beskoski, V.; Simic, M.; Trifunovic, S.; Tesevic, V.; Vajs, V.; Milosavljevic, S. Pyrrolizidine alkaloids from seven Senecio species wild-growing in Serbia and Montenegro. J. Serbian Chem. Soc. 2009, 74, 27-34.

3. Mandic, B.; Godevac, D.; Vujsic, L.J.; Trifunovic, S.; Tesevic, V.; Vajs, V.; Milosavljevic, S. Semiquinol and phenol compounds from seven Senecio species. Chem. Papers 2011, 65, 90-92.

4. Christov, V.; Kostova, N.; Evstatieva, L. 6-Angeloylplatynecine: A new alkaloid from Senecio nemorensis subsp. fuchsii (C.C. Gmelin) celak. Nat. Prod. Res. 2005, 19, 389-392.

5. Kostova, N.; Christov, V.; Cholakova, M.; Nikolova, E.; Evstatieva, L. Pyrrolizidine alkaloids from Bulgarian species of the genus Senecio. J. Serbian Chem. Soc. 2006, 71, 1275-1280.

6. Dreger, M.; Stanisławska, M.; Krajewska-Patan, M.; Mielcarek, S.; Łukasz Mikołajczak, P.; Buchwald, W. Pyrrolizidine alkaloids - Chemistry, biosynthesis, pathway, toxicity, safety and perspectives of medicinal usage. Herba Pol. 2009, 55, 127-147. 
7. Roeder, E. Medicinal plants in Europe containing pyrrolizidine alkaloids. Pharmazie 1995, 50, 83-98.

8. Roeder, E. Analysis of pyrrolizidine alkaloids. Curr. Org. Chem. 1999, 3, 557-576.

9. Ivanova, A.; Serly, J.; Christov, V.; Stamboliyska, B.; Molnar, J. Alkaloids derived from genus Veratrum and Peganum of Mongolian origin as multidrug resistance inhibitors of cancer cells. Fitoterapia 2011, 82, 570-575.

10. Cheeke, P.R. Alkaloids. In Toxicants of Plant Origin; CRC Press: Boca Raton, FL, USA, 1989; Volume 1.

11. Bigazzi, M.; Nardi, E.; Selvi, F. Palynological contribution to the systematics of Rindera and the allied genera Paracaryum and Solenanthus (Boraginaceae-Cynoglosseae). Willdenowia 2006, 36, $37-46$.

12. Smith, L.W.; Culvenor, C.J. Plant sources of hepatoxic pyrrolizidine alkaloids. J. Nat. Prod. 1981, 44, 129-152.

13. Jordan, M.A.; Wilson, L. Microtubules as a target for anticancer drugs. Nat. Rev. Cancer 2004, 4, 253-265.

14. Singh, P.; Rathinasamy, K.; Mohan, R.; Panda, D. Microtubule assembly dynamics: An attractive target for anticancer drugs. IUBMB Life 2008, 60, 368-375.

15. Kingston, D.G.I. Tubulin-interactive natural products as anticancer agents. J. Nat. Prod. 2009, 72 , 507-515.

16. Yuldasheva, N.K.; Ul'chenko, N.T.; Glushenkova, A.I. Lipids from fruit of Rindera oblongifolia. Chem. Nat. Compd. 2012, 47, 981-982.

17. Velasco, L.; Goffman, F.D. Chemotaxonomic significance of fatty acids and tocopherols in Boraginaceae. Phytochemistry 1999, 52, 423-426.

18. Taghreed, A.I. Chemical composition and biological activity of extracts from Salvia bicolor Desf. growing in Egypt. Molecules 2012, 17, 11315-11334.

19. Mandana, B.; Russly, A.R.; Farah, S.T.; Noranizan, M.A.; Md. Zaidul, I.S.; Ali, G. Supercritical carbon dioxide extraction of eeed oil from winter melon (Benincasa hispida) and its antioxidant activity and fatty acid composition. Molecules 2013, 18, 997-1014.

20. Sousa, A.; Casal, S.; Bento, A.; Malheiro, R.; Oliveira, M.B.; Pereira, J.A. Chemical characterization of "Alcaparras" stoned table olives from northeast Portugal. Molecules 2011, 16, 9025-9040.

21. Logie, C.; Grue, M.; Liddel, J. Proton NMR spectroscopy of pyrrolizidine alkaloids. Phytochemistry 1994, 37, 43-109.

22. Roeder, E. Carbon-13 NMR spectroscopy of pyrrolizidine alkaloids. Phytochemistry 1990, 29, $11-29$.

23. Fu, P.P.; Xia, Q.; Lin, G.; Chou, M.W. Pyrrolizidine Alkaloids-Genotoxicity, metabolism; enzymes, metabolic activation, and mechanisms. Drug Metab. Rev. 2004, 36, 1-55.

24. Saburo, K.; Sei-ichi, U. A new unsaturated fat acid, $\mathrm{C}_{10} \mathrm{H}_{18} \mathrm{O}_{2}$, present in the oil of Rindera obtusiloda. Bull. Chem. Soc. Jpn. 1937, 12, 226.

25. Miller, R.W.; Earle, F.R.; Wolff, I.A.; Barclay, A.S. Search for new seed oils. XV. Oils of Boraginaceae. Lipids 1968, 3, 443-445.

26. Gaskin, F.; Cantor, C.R.; Shelanski, M.L. Turbidimetric studies of the in vitro assembly and disassembly of porcine neurotubules. J. Mol. Biol. 1974, 89, 737-755. 
27. Pesic, M.; Brankovic, J.; Aljancic, I.; Todorovic, N.; Jadranin, M.; Vajs, V.; Tesevic, V.; Vuckovic, I.; Momcilovic, M.; Markovic, I.; et al. New anti-cancer characteristics of jatrophane diterpenes from Euphorbia dendroides. Food Chem. Toxicol. 2011, 49, 3165-3173.

28. Shelanski, M.L.; Gaskin, F.; Cantor, C.R. Microtubule assembly in the absence of added nucleotides. Proc. Natl. Acad. Sci. USA 1973, 70, 765-768.

Sample Availability: Not available.

(C) 2013 by the authors; licensee MDPI, Basel, Switzerland. This article is an open access article distributed under the terms and conditions of the Creative Commons Attribution license (http://creativecommons.org/licenses/by/3.0/). 